\title{
'Stolo' Strawberry
}

Chaim Kempler², Hugh A. Daubeny ${ }^{1}$, Brian Harding, and Lisa Frey

Pacific Agri-Food Research Centre, Agriculture and Agri-Food Canada, P.O. Box 10006947 \#7 Highway, Agassiz, BC, Canada V0M 1A0

\section{Tom E. Baumann}

Agriculture Department, University of the Fraser Valley, Chilliwack, BC, Canada V2P $6 T 4$

Chad E. Finn

U.S. Department of Agriculture-Agricultural Research Service, Horticultural Crops Research Unit, Northwest Center for Small Fruit Research, Corvallis, OR 97330

\section{Shahrokh Khanizadeh \\ Horticulture Research and Development Centre, Agriculture and Agri-Food Canada, St-Jean-sur-Richelieu, QC, Canada J3B 3E6}

\section{Andrew R. Jamieson}

Atlantic Food and Horticulture Research Center, Agriculture and Agri-Food Canada, Kentville, NS, Canada B4N 1J5

\section{Kenna MacKenzie}

Pacific Agri-Food Research Centre, Agriculture and Agri-Food Canada, Summerland, BC, Canada VOH $1 Z 0$

\section{Patrick P. Moore}

Department of Horticulture and Landscape Architecture, Washington State University, Puyallup, WA 98371

\section{Mark Sweeney}

BC Ministry of Agriculture, Fisheries and Food, Abbotsford, BC, Canada V3G $2 M 3$

Additional index words. fruit breeding, fruit quality, virus tolerance, winter hardiness, disease resistance, root weevils, Otiorhynchus sulcatus tolerance

'Stolo' is a new June-bearing strawberry (Fragaria ×ananassa Duchesne ex Rozier) cultivar from the Agriculture and Agri-Food Canada (AAFC), Pacific Agri-Food Research Center (PARC) in Agassiz, released in coop-

Received for publication 18 Feb. 2011. Accepted for publication 16 May 2011.

This research was partially funded by the Fraser Valley Strawberry Growers' Association, Washington Strawberry Commission, the Lower Mainland Horticultural Improvement Association, and Agriculture and Agri-Food Canada.

We gratefully acknowledge the assistance of $\mathrm{M}$. Bodnar, J. Dawson, G. Kliever, and M. Thomson at the Pacific Agri-Food Research Centre, Agassiz, BC. We acknowledge the help of K. Lewers, USDA-ARS Beltsville, MA, and S. Pannu, California Seed \& Plant Lab, Ltd., Elverta, CA, for help with the interpretation of the molecular characterization data. Contribution no. 800 .

Mention of trade names or commercial products in this article is solely for the purpose of providing specific information and does not imply recommendation or endorsement by the authors or their agencies.

${ }^{1}$ Research scientist (retired).

${ }^{2}$ To whom reprint requests should be addressed; e-mail chaim.kempler@agr.gc.ca. fruited Pacific-Northwest (PNW) cultivar released by the WSU breeding program in Puyallup, WA (Moore, 1995; Moore et al., $1995)$ that is well adapted to Fraser Valley conditions. 'Whonnock' is a cross between 'Sumas' and 'Hapil' and was released from the PARC program in 1999. Although it was not adopted by growers in the PNW because of its unattractive, rough, and seedy fruit, 'Whonnock' was used extensively as a parent by the PARC breeding program because of its high yields and excellent tolerance to root weevils and soilborne diseases.

'Stolo' was tested at the AAFC-PARC Research Substation, Abbotsford, BC, the Oregon State University (OSU)-North Willamette Research and Extension Center (Aurora, OR), WSU Puyallup, at AAFC sites in St-Jean-sur-Richelieu, QC, and Kentville, NS, and in growers' fields in British Columbia. At the research facilities, 'Stolo' was planted in multiple non-replicated and replicated matted row system trials. 'Stolo' was evaluated for 7 years (1999 to 2006) at the PARC substation. Plants were grown in eightplant plots and were spaced $30 \mathrm{~cm}$ apart within the row and $122 \mathrm{~cm}$ between the rows. Rows were narrowed with a rotovator to $40 \mathrm{~cm}$ in March when new growth started. Fruits were harvested once per week, and fruit size for the season was calculated as a weighted mean based on the weight of randomly selected subsamples of 25 fruit at each harvest (Table 1). Fruit firmness was measured as the force required for a $4 \mathrm{~mm}$ diameter cylinder to penetrate to a depth of $6 \mathrm{~mm}$ in 10 randomly selected fruit on three harvest dates in each season (early, mid, and late harvest) (Hunter Spring Mechanical Force Gauge Series L; Ametek, Hatfield, PA). The percentages of Botrytis fruit rot were calculated after 24 and $48 \mathrm{~h}$ on 10 randomly selected fruit on three harvest dates each season and kept on plates at $20{ }^{\circ} \mathrm{C}$ under plastic wrap. The planting included other cultivars commonly grown in the PNW (Finn et al., 2009; P.P. Moore, personal communication). All data were subjected to analysis of variance using the General Linear Model Procedure of SAS (SAS Institute, Cary, NC) and means were separated using protected least significant difference.

\section{Performance}

(Otiorhynchus sp.). Its glossy red fruit is primarily suited for the fresh market (Fig. 1A). The name 'Stolo' follows the PARC tradition of naming cultivars using names in the language of First Nations and comes from the Stolo First Nation residing in the Fraser Valley, BC, where the cultivar was developed and is currently grown. The word Stolo means "people of the river."

\section{Origin}

'Stolo', tested as BC96-33-4, was bred by C. Kempler in 1995 and selected in Abbotsford, BC, by C. Kempler and H.A. Daubeny in 1997 among the progeny of a cross between 'Puget Reliance' and 'Whonnock' (Fig. 2). 'Puget Reliance' is a high-yielding, large- 
'Puget Reliance', which are three of the main cultivars grown in the PNW (Table 1). 'Stolo' yield was similar to 'Tillamook', which is known for its productivity. 'Whonnock', a parent of 'Stolo', was the only cultivar that had significantly higher yield than 'Stolo'. 'Stolo' fruit size in these trials was larger than 'Totem' but smaller than 'Firecracker', 'Pinnacle', 'Rainier', and 'Tillamook'. Botyritis fruit rot percentage was similar to all of the other cultivars (Table 2) in the trial but was greater than 'Puget Summer', which ripens at a later, and typically drier, time of year (Table 1). The 'Stolo' harvest season is very similar to that of 'Rainier', 3 to $4 \mathrm{~d}$ later than 'Totem' and 4 to 6 $\mathrm{d}$ earlier than 'Puget Summer', which is known for its late-season production (Moore and Finn, 2002). The soluble solid content of 'Stolo' was similar to the other cultivars (Table 2). The titratable acidity of 'Stolo' fruit was significantly higher than that of the other tested cultivars except for 'Totem' (Table 2). Its $\mathrm{pH}$ was similar to the other tested cultivars (Table 2). The firmness of 'Stolo' fruit was softer than that of 'Pinnacle' and 'Redcrest' but not significantly different from the other cultivars. Its firmness is suitable for the fresh and processing markets, and it exhibits good postharvest quality.

In multiple-year, multiple-cultivar trials at the OSU-North Willamette Research and Extension Center, 'Stolo' produced a higher yield than that of 'Totem' (data not shown; C. Finn and P.P. Moore, personal communication). At a WSU-Mount Vernon trial, 'Stolo' tended to produce a high yield (Finn et al., 2009). In Kentville, NS, from 2005 to 2007, 'Stolo' demonstrated good plant health and high vigor. Large to medium-sized, symmetrical, bright red berries were produced in the late to very late season. 'Stolo' was also productive at Kentville, indicating broad adaptability (A.R. Jamieson, personal communication).

\section{Plant Description}

'Stolo' plants are vigorous with an erect growth habit and sufficient runner production to create a satisfactory matted row. 'Stolo' plants produce uniform matted rows with higher vigor and better cover on the second
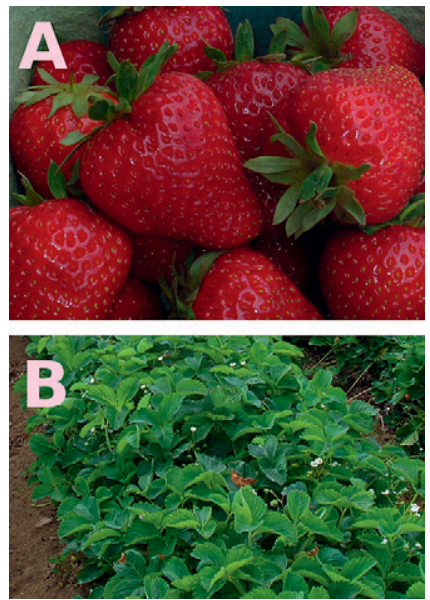

Fig. 1. 'Stolo' strawberry (A) fruit and (B) matted row showing some tip-burn-like symptoms. year growth than most of the other cultivars with which it was compared (Table 3). A comparison of 'Stolo' leaf characteristics with other PNW cultivars is presented in Table 4. 'Stolo' petioles are longer than the other cultivars in the trial. Its peduncles are shorter than 'Totem' and not significantly different from 'Puget Reliance'. The situation of 'Stolo' inflorescence is slightly lower in the canopy than 'Totem' and 'Puget Reliance'. The leaves and petioles are pubescent, which gives them a silvery greenish appearance. 'Stolo' is easily distinguished in the field by its erect growth habit and its heavily pubescent leaves, which it inherited from its parent, 'Whonnock'. Under vigorous growing conditions, some leaves show

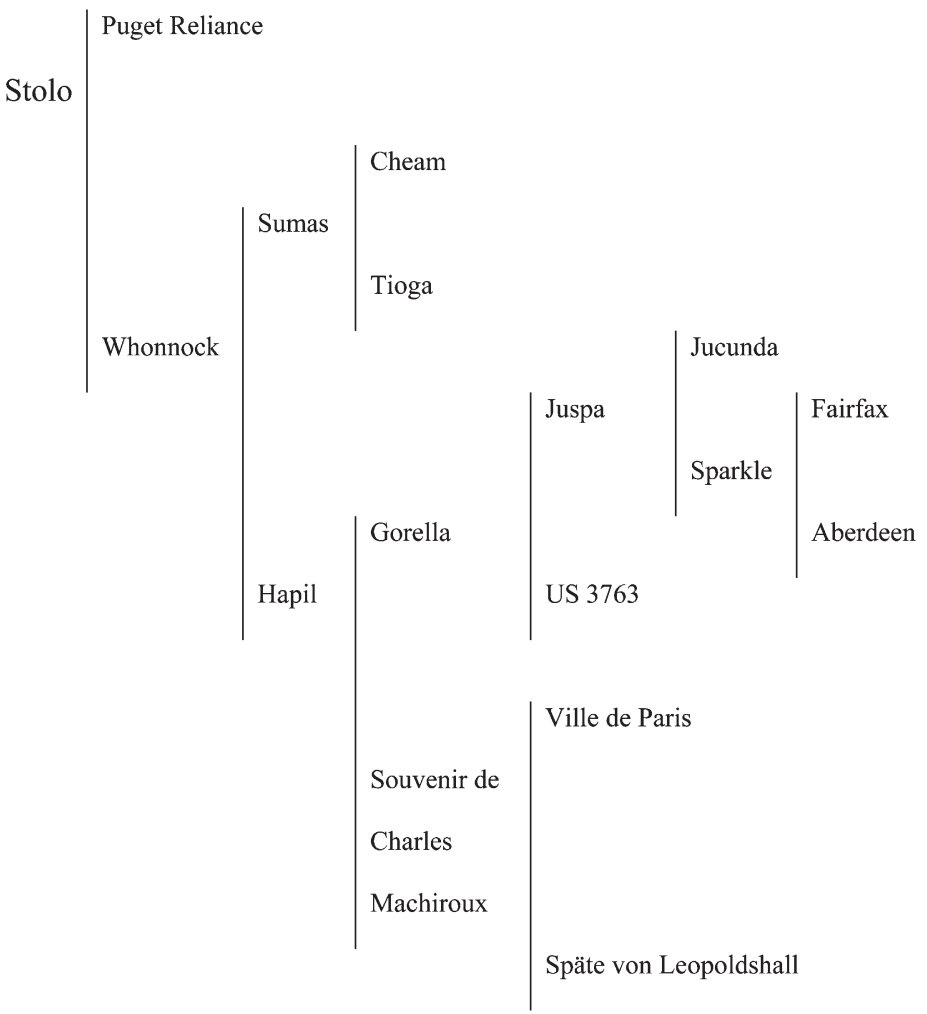

Fig. 2. Pedigree of 'Stolo' strawberry.

Table 1. Yield, fruit weight, and harvest season of 'Stolo' and other Pacific-Northwest cultivars. ${ }^{\text {. }}$

\begin{tabular}{lccccccc}
\hline & & & & \multicolumn{3}{c}{ Harvest season (date) } & Harvest \\
\cline { 5 - 6 } Cultivar & $\begin{array}{c}\text { Yield } \\
\left(\mathrm{kg} / 10 \mathrm{~m}^{2}\right)\end{array}$ & $\begin{array}{c}\text { Fruit } \mathrm{wt}^{\mathrm{y}} \\
(\mathrm{g})\end{array}$ & $\begin{array}{c}\text { Fruit rot } \\
(\%)\end{array}$ & $\begin{array}{c}\text { Start } \\
(5 \%)\end{array}$ & $\begin{array}{c}\text { Mid point } \\
(50 \%)\end{array}$ & $\begin{array}{c}\text { End } \\
(95 \%)\end{array}$ & $\begin{array}{c}\text { (5)ation } \\
(\mathrm{d})\end{array}$ \\
\hline Stolo & 11.94 & 10.2 & 13.8 & 9 June & 20 June & 30 June & 22 \\
Benton & 10.79 & 10.1 & 10.5 & 4 June & 14 June & 27 June & 24 \\
Firecracker & 11.14 & 11.8 & 13.2 & 4 June & 14 June & 24 June & 21 \\
Puget Reliance & 8.57 & 11.0 & 11.6 & 5 June & 13 June & 26 June & 22 \\
Puget Summer & 7.98 & 9.6 & 7.0 & 15 June & 24 June & 4 July & 20 \\
Pinnacle & 10.21 & 13.2 & 16.2 & 2 June & 12 June & 25 June & 24 \\
Rainier & 7.86 & 11.5 & 17.4 & 10 June & 20 June & 1 July & 22 \\
Redcrest & 10.22 & 10.6 & 11.4 & 7 June & 17 June & 30 June & 24 \\
Sumas & 10.13 & 9.3 & 14.1 & 5 June & 14 June & 26 June & 21 \\
Tillamook & 11.98 & 16.0 & 9.1 & 2 June & 12 June & 25 June & 24 \\
Totem & 8.34 & 8.9 & 13.1 & 6 June & 16 June & 26 June & 21 \\
Whonnock & 14.47 & 9.4 & 17.8 & 5 June & 16 June & 26 June & 22 \\
LSD & 2.57 & 1.2 & 5.0 & 2 & 3 & 2 & 2 \\
\hline
\end{tabular}

${ }^{\mathrm{z}}$ Means are calculated from two to four replications in seven plantings harvested in 1999, 2000, 2001, 2003, 2004, 2005, and 2006, respectively.

${ }^{y}$ Fruit weight is an overall mean for all harvest years based on means of 25 fruit subsampled from each harvest.

${ }^{\mathrm{x}}$ Mean separation within columns with least significant difference (LSD), $P=0.05$. 
Table 2. Fruit traits of 'Stolo' and other Pacific-Northwest cultivars. ${ }^{\mathrm{z}}$

\begin{tabular}{|c|c|c|c|c|c|c|}
\hline Cultivar & $\mathrm{pH}$ & $\begin{array}{c}\text { Titratable } \\
\text { acidity }(\%)\end{array}$ & $\begin{array}{c}\text { Soluble } \\
\text { solids }^{\mathrm{y}}(\%)\end{array}$ & $\begin{array}{l}\text { Firmness }^{\mathrm{x}} \\
\text { (g) }\end{array}$ & $\begin{array}{c}\text { Botrytis- } \\
\text { incited fruit } \\
\text { rot after } 24 \mathrm{~h}^{\mathrm{w}}(\%)\end{array}$ & $\begin{array}{c}\text { Botrytis- } \\
\text { incited fruit } \\
\text { rot after } 48 \mathrm{~h}^{\mathrm{w}} \\
(\%)\end{array}$ \\
\hline$\overline{\text { Stolo }}$ & 3.52 & 0.90 & 8.7 & 279 & 11.1 & 38.4 \\
\hline Firecracker & - & - & 8.6 & 320 & 9.2 & 24.2 \\
\hline Puget Reliance & 3.52 & 0.73 & 8.3 & 284 & 8.5 & 29.6 \\
\hline Puget Summer & 3.46 & 0.45 & 7.6 & 317 & 0.0 & 6.3 \\
\hline Pinnacle & 3.68 & 0.42 & 8.0 & 461 & 5.2 & 34.8 \\
\hline Rainier & - & - & 7.7 & 257 & 1.3 & 21.3 \\
\hline Redcrest & - & - & 9.4 & 523 & 4.0 & 25.9 \\
\hline Sumas & 3.67 & 0.38 & 8.0 & 300 & 5.4 & 24.9 \\
\hline Tillamook & 3.50 & 0.68 & 8.3 & 379 & 14.1 & 29.7 \\
\hline Totem & 3.65 & 0.78 & 8.3 & 386 & 5.5 & 29.6 \\
\hline Whonnock & - & - & 8.1 & 319 & 8.4 & 32.0 \\
\hline $\mathrm{LSD}^{\mathrm{v}}$ & 0.12 & 0.14 & 1.6 & 108 & 12.0 & 21.0 \\
\hline
\end{tabular}

${ }^{\mathrm{z}}$ Means are calculated from seven plantings harvested in 1999, 2000, 2001, 2003, 2004, 2005, and 2006, respectively.

y Titratable acidity expressed as percent citric acid; percent soluble solids at $20^{\circ} \mathrm{C}$.

${ }^{\mathrm{x}}$ Measured as the force required for a $4 \mathrm{~mm}$ diameter cylinder to penetrate to a depth of $6 \mathrm{~mm}$ in 10 randomly selected fruit on three harvest dates in each season.

${ }^{\text {w}}$ Percent of Botrytis incited fruit scored after 24 and $48 \mathrm{~h}$ on 10 randomly selected fruit on three harvest dates in each season placed on a plate at $20^{\circ} \mathrm{C}$ and covered with plastic wrap.

${ }^{v}$ Mean separation in columns by least significant difference (LSD), $P=0.05$.

Table 3. Rating of plant vigor and plot cover of 'Stolo' and other Pacific-Northwest cultivars grown in matted rows in Abbotsford, $\mathrm{BC}^{\mathrm{z}}$.

\begin{tabular}{|c|c|c|c|c|c|c|}
\hline \multirow[b]{2}{*}{ Clone } & \multicolumn{3}{|c|}{ Plant vigor $^{2}$} & \multicolumn{3}{|c|}{ Plot cover ${ }^{2}$} \\
\hline & Planting yr & Yr 1 & Yr 2 & Planting yr & Yr 1 & Yr 2 \\
\hline Benton & 7.0 & 4.4 & 4.1 & 6.3 & 3.8 & 3.3 \\
\hline Hood & 8.5 & 4.7 & 2.8 & 9.5 & 4.7 & 1.0 \\
\hline Pinnacle & 8.3 & 6.5 & 7.5 & 7.9 & 1.0 & 6.5 \\
\hline Puget Reliance & 8.1 & 5.7 & 5.0 & 7.6 & 6.0 & 4.3 \\
\hline Rainier & 9.7 & 5.4 & 0.8 & 9.1 & 4.0 & 1.4 \\
\hline Stolo & 8.5 & 6.4 & 6.9 & 8.9 & 6.9 & 6.6 \\
\hline Sumas & - & 4.6 & 4.4 & - & 4.3 & 3.1 \\
\hline Tillamook & 6.8 & 7.3 & 7.0 & 6.3 & 7.3 & 7.4 \\
\hline Totem & 8.3 & 5.5 & 4.1 & 7.9 & 4.7 & 3.7 \\
\hline Whonnock & 10.0 & 5.9 & 5.7 & 10.0 & 6.5 & 6.9 \\
\hline $\operatorname{LSD}^{\mathrm{x}}$ & 1.6 & 2.1 & 2.5 & 1.8 & 1.7 & 2.1 \\
\hline
\end{tabular}

${ }^{\mathrm{z}}$ Rating of seven replicated trials planted between 1999 and 2006.

${ }^{\mathrm{y}}$ Scored on a 0 to 10 scale $(0=$ low vigor or low plot cover; $10=$ high vigor or plot cover $)$.

${ }^{\mathrm{x}}$ Mean separation in columns by least significant difference (LSD), $P=0.05$.

Table 4. Leaf and inflorescence characteristics of 'Stolo' compared with other Pacific-Northwest cultivars.

\begin{tabular}{lccccc}
\hline & \multicolumn{4}{c}{ Central leaflet $^{z}$} \\
\cline { 2 - 6 } Clone & Length $(\mathrm{cm})$ & Width $(\mathrm{cm})$ & $\begin{array}{c}\text { Serration } \\
\text { no. }\end{array}$ & Petiole $(\mathrm{cm})$ & $\begin{array}{c}\text { Peduncle }^{z} \\
(\mathrm{~cm})\end{array}$ \\
\hline Puget Reliance & 8.0 & 6.5 & 18.3 & 20.8 & 11.2 \\
Stolo & 8.2 & 6.6 & 19.9 & 23.7 & 12.0 \\
Tillamook & 10.0 & 8.4 & 20.0 & 21.4 & 9.8 \\
Totem & 7.5 & 6.7 & 22.4 & 21.8 & 13.6 \\
LSD $^{y}$ & 0.4 & 0.4 & 1.0 & 1.6 & 1.3 \\
\hline
\end{tabular}

${ }^{\mathrm{z}}$ Mean of 10 leaves and inflorescences from each of four replicates collected July 2006.

${ }^{\mathrm{y}}$ Mean separation in columns by least significant difference (LSD), $P=0.05$.

denaturation step at $94{ }^{\circ} \mathrm{C}$, a $30 \mathrm{~s}$ annealing step at $60{ }^{\circ} \mathrm{C}$, and a $45 \mathrm{~s}$ extension step at $72^{\circ} \mathrm{C}$. A final extension step at $72{ }^{\circ} \mathrm{C}$ for 15 min was included. SSR products were separated by capillary electrophoresis using the ABI 3100 16 capillary Genetic Analyzer (Life Technologies Corporation, Carlsbad, CA) and sized by comparison with the Applied Biosystems Genescan 400HD ROX size standard (Life Technologies Corporation, Carlsbad, CA).

\section{Disease and Pest Reaction}

'Stolo' is highly tolerant to the virus complex that consists of strawberry mottle, strawberry crinkle, and strawberry mild yellow-edge that are transmitted by aphids and commonly present in the PNW (Martin and Tzanetakis, 2006). 'Stolo' shows susceptibility to powdery mildew [Podosphaera aphanis (Wallr.) U. Braun \& S. Takam, formerly Sphaerotheca macularis Wallr. Ex. Fr.] when grown in a greenhouse but it does not appear to be a problem when grown under field conditions. 'Stolo' shows good field resistance to red stele caused by Phytophthora fragariae Hickman. 'Stolo' is highly tolerant to high populations of black vine weevil (Otiorhynchus sulcatus, Fabricius), obscure root weevil (Sciopithes obscurus, Horn) and strawberry root weevil (O. ovatus) larvae. In field observations, 'Stolo' and its parent, 'Whonnock', performed very well under heavy root weevil pressure (Kempler et al., 2007; P.P. Moore, C. Finn, and C. Kempler, unpublished data). In a trial, young, potted, daughter plants of 'Stolo', 'Kent', and 'Annapolis' were artificially inoculated with eggs of black vine weevil. After 6 weeks, all 'Stolo' plants were healthy with good root mass, whereas the other two cultivars showed poor growth with heavy root feeding (Kempler et al., 2007). Although 'Kent' and 'Annapolis' roots appeared to be pruned off by larval feeding, many 'Stolo' roots showed only surface feeding. This apparent tolerance to larval feeding was also observed on the 'Stolo' parent, 'Whonnock'. The other parent, 'Puget Reliance', is susceptible to weevils (Moore et al., 1995). 'Stolo' is tolerant only to the larva stage, because the plants will still support adult weevils that feed on strawberry foliage resulting in characteristic notching. However, root weevil feeding by adults causes only cosmetic damage, whereas larval feeding on the roots and tunneling through the crown can cause significant plant damage. 'Stolo's tolerance may be heritable because one of its parents, 'Whonnock', is also tolerant. Therefore, it has potential for growers in areas with known root weevil populations and in breeding programs.

'Stolo' is especially noted for maintaining economical yield on commercial growers fields attributed to the tolerance to root weevils that has been inherited from its parent, 'Whonnock', and to tolerance to virus complexes common in the PNW (M. Sweeney, personal observation).

\section{Availability}

'Stolo' was released in 2006 because of its excellent fruit quality, high yield, and resistance to pests and diseases. Certified 'Stolo' plants are being propagated under royalty agreements with Sakuma Bros Farm, Burlington, WA. For licensing information, contact Okanagan Plant Improvement Company (PICO), P.O. Box 6000, Summerland, BC, V0H 1Z0, Canada. E-mail: info@picocorp.com.

\section{Literature Cited}

Finn, C.F., P.P. Moore, C. Kempler, B.M. Yorgey, B.C. Strik, and R.R. Martin. 2009. 'Valley Red' strawberry. HortScience 44:1468-1471.

Kempler, C., H.A. Daubeny, and K. MacKenzie. 2007. Recent developments in the Pacific AgriFood Centre strawberry breeding programme. Proc. 2007 N. Amer. Strawberry Symp. NASS/ NASGA Proc. p. 81-82.

Lewers, K.S., S.M.N. Styan, S.C. Hokanson, and N.V. Bassil. 2005. Strawberry GenBank-derived and genomic simple sequence repeat (SSR) markers and their utility with strawberry, blackberry, and red and black raspberry. J. Amer. Soc. Hort. Sci. 130:102-115.

Martin, R.R. and I.E. Tzanetakis. 2006. Characterization and recent advances in detection of strawberry viruses. Plant Dis. 90:384-396.

Moore, P.P. 1995. Strawberry plant 'Puget Reliance'. U.S. Patent 9,310. U.S. Patent and Trademark Office, Washington, DC.

Moore, P.P. and C.E. Finn. 2002. 'Schwartze' ('Puget Summer') strawberry. HortScience 37:230-232.

Moore, P.P., T.M. Sjulin, and C.H. Shanks. 1995. 'Puget Reliance' strawberry. HortScience 30: 1468-1469. 